\title{
WETTABILITY OF THE SURFACE OF HEAT-TREATED JUVENILE TEAK WOOD ASSESSED BY DROP SHAPE ANALYZER
}

\author{
Juliana de Oliveira Lopes ${ }^{1}$, Rosilei Aparecida Garcia $^{2, \bullet}$, Alexandre Miguel do Nascimento ${ }^{2}$
}

\begin{abstract}
This study investigated the effect of the heat treatment on the wettability of the surface of juvenile teak (Tectona grandis) wood assessed by drop shape analyzer. Heartwood and sapwood samples were heat-treated at 180 and $200^{\circ} \mathrm{C}$. Contact angle measurements were done every $5 \mathrm{~s}$ for $120 \mathrm{~s}$ using a KRÜSS DSA100. Heartwood had lower wettability than sapwood. Heat-treatment decreased the surface wettability of both heartwood and sapwood, especially in the wood treated at $200^{\circ} \mathrm{C}$. Heartwood had lower wettability than sapwood, even after heat treatment.
\end{abstract} grandis.

Keywords: Chemical modification, contact angle, heartwood, hygroscopicity, sapwood, Tectona

\section{INTRODUCTION}

The heat treatment or thermal modification has been widely studied because it promotes several advantages to the wood such as lower hygroscopicity, lower equilibrium moisture content, higher dimensional stability (Giebeler 1983), higher decay fungi resistance (Lekounougou and Kocaefe 2013) and color change (Garcia et al. 2014, Lopes et al. 2014). The heat-treated wood undergoes physical (Awoyemi and Jones 2011, Bernabei and Salvatici 2016) and chemical modifications (Esteves et al. 2011) but the last one is the most important in terms of impact on the properties of the material. Among the chemical changes of the wood following heat treatment, we can highlight the degradation of the hemicelluloses, changes in the lignin structure due to its crosslinking with the products from the thermal degradation, modifications of the cellulose (degradation of the amorphous region and increase in crystallinity) (Bhuiyan and Hirai 2000), volatilization of the original extractives and formation of the new compounds such as anhydrosugars and phenolic compounds (Esteves et al. 2011). Therefore, several chemical reactions occur during the heat treatment such as hydrolysis, oxidation (Popescu and Popescu 2013) causing the reduction of free hydroxyl groups and the surface inactivation. The surface inactivation affects the wettability which plays an important role in the adhesion and coating application (paints and varnishes) processes.

The wettability of the wood surface is a complex phenomenon and depends on its physical and chemical properties. The physical factors include cell morphology, roughness, specific surface area

\footnotetext{
${ }^{1}$ Doctor student. Departamento de Produtos Florestais Departamento de Produtos Florestais, Instituto de Florestas, Universidade Federal Rural do Rio de Janeiro (UFRRJ), Rio de Janeiro, Brazil.

${ }^{2}$ Professor. Departamento de Produtos Florestais Departamento de Produtos Florestais, Instituto de Florestas, Universidade Federal Rural do Rio de Janeiro (UFRRJ), Rio de Janeiro, Brazil.

•Corresponding author: rosileigar@ufrrj.br

Received: 15.01.2017 Accepted: 02.12.2017
} 
and permeability while the chemical factors include the functional groups, molecular and elemental composition (Tshabalala 2005). The physical and chemical factors determine the surface wettability which may be analyzed by the contact angle measurements assessed by several techniques, among them the most widely used techniques are the telescope-goniometer method, a direct measurement of the tangent angle at the three-phase contact point on a sessile drop profile and the Wilhelmy plate method, an indirect measurement using a thin, smooth and vertical plate suspended in a balance that measures the change of weight during immersion and removal of the plate from a liquid; and the drop shape analyzer (DSA), one of the most recent and accurate techniques (Yuan and Lee 2013).

Teak wood grown in Brazil has shorter cutting cycles when compared to its pays of origin due to the favorable edaphoclimatic conditions and silvicultural treatments; however, the juvenile wood exhibits a high proportion of sapwood, which has physical, chemical and aesthetic properties (color and design) quite different from heartwood. Teak heartwood has a good dimensional stability and high natural durability due to the presence of some substances such as caoutchouc, a latex responsible for the resistance to water absorption (Yamamoto et al. 1998); tectoquinone, 2-hydroxymethyl anthraquinone and lapachol, preservatives of phenolic nature present in the wood cells (Niamké et al. 2011). Teak sapwood exhibits light color, lower extractive content and low durability. Heat treatments allow to standardize the color of teak pieces containing heartwood/sapwood (Lopes et al. 2014) and in this way add value to the final product. Heat treatments cause physico-chemical modification at different levels depending on the characteristics of the material, therefore studies on the heat-treated sapwood and heartwood will contribute to a better understanding about the wettability of the surface of the heattreated teak wood.

In this context, the objective of this study was to investigate the effect of the heat treatment on the surface wettability of juvenile teak wood (heartwood and sapwood) assessed by DSA method.

\section{MATERIAL AND METHODS}

\section{Material and heat treatment}

Teak (Tectona grandis L. f.) wood samples with nominal dimensions of $150 \times 75 \times 20 \mathrm{~mm}^{3}$ were obtained from six trees of 12 years old. The material was separated in heartwood and sapwood, air dried and conditioned at $20^{\circ} \mathrm{C}$ and $65 \% \mathrm{RH}$ in a climate chamber until constant mass.

The heat treatment was carried out in an electric laboratorial muffle furnace from Linn Elektro Therm, with dimensions of $600 \times 600 \times 700 \mathrm{~mm}^{3}$ equipped with a system of temperature and time control. The treatment was conducted in four steps at two different temperatures: 180 and $200^{\circ} \mathrm{C}$. The four steps were: (1) heating up to $100^{\circ} \mathrm{C}$ for $2 \mathrm{~h}$; (2) increase of temperature from $100^{\circ} \mathrm{C}$ to final temperature $\left(180\right.$ or $200^{\circ} \mathrm{C}$ ) for $30 \mathrm{~min}$; (3) treatment time in the selected temperature for $2 \mathrm{~h}$ and 30 min; and (4) cooling for approximately $1 \mathrm{~h}$. The initial moisture content of the samples was $8-10 \%$ (based on the oven-dry of the wood). Heat-treated samples were conditioned at $20^{\circ} \mathrm{C}$ and $65 \% \mathrm{RH}$ until constant mass. The moisture content of the heat-treated heartwood and sapwood samples was $4 \%$ to $4,8 \%$.

\section{Contact angle analysis}

The contact angle analysis was assessed by the DSA100 drop shape analyzer, version 1.92 from KRÜSS GmbH (Hamburg, Germany). The liquid probe was distilled water at $20^{\circ} \mathrm{C}$ which was applied with a dosing syringe of $100 \mu \mathrm{l}$, needle of $0,5 \mathrm{~mm}$ in diameter at $3 \mathrm{~mm}$ height from sample surface. A $5 \mu \mathrm{l}$ drop volume was standardized for all samples. The drop shape was analyzed every $5 \mathrm{~s}$ for 120 $\mathrm{s}$, resulting in 24 readings at each point. Contact angle measurements were made on five points per sample with five replicates per treatment. Three variables were evaluated: initial contact angle $\left(\mathrm{CA}_{\text {initial }}\right)$ $=5 \mathrm{~s}$ after water droplet deposition on the sample surface; final contact angle $\left(\mathrm{CA}_{\text {final }}\right)=120 \mathrm{~s}$ after water droplet deposition on the sample surface; and mean contact angle $\left(\mathrm{CA}_{\text {mean }}\right)=$ average of 24 readings taken for $120 \mathrm{~s}$. 


\section{Experimental design and statistical analysis}

The experimental design was composed of two factors (independent variables): wood type (heartwood and sapwood) and temperature (control, $180^{\circ} \mathrm{C}$ and $200^{\circ} \mathrm{C}$ ), resulting in six treatment combinations. The dependent variables were the initial contact angle $\left(\mathrm{CA}_{\text {initial }}\right)$, final contact angle $\left(\mathrm{CA}_{\text {final }}\right)$ and mean contact angle $\left(\mathrm{CA}_{\text {mean }}\right)$.

Statistical analyzes were performed at Statistic 10.0. $\mathrm{CA}_{\text {initial }}$ and $\mathrm{CA}_{\text {final }}$ data were subjected to analysis of variance (Anova) and Tukey's range test at 95\% probability level. The normality and homoscedasticity were verified by Shapiro-Wilk and Levene's tests, respectively, at 95\% probability level. A logarithmic transformation ( $\log 10$ ) was used to $\mathrm{CA}_{\text {final }}$ (heartwood + sapwood). $\mathrm{CA}_{\text {mean }}$ data did not meet the Anova assumptions when both independent variables (wood type and temperature) were included together in the analysis therefore they were analyzed separately. An Anova was performed to evaluate the effect of the temperature on $\mathrm{CA}_{\text {mean }}$ in each wood group and the Wilcoxon-Mann-Whitney nonparametric test was used to compare heartwood and sapwood.

\section{RESULTS AND DISCUSSION}

\section{Surface wettability}

\section{Behavior of the contact angle as a function of time}

Figure 1 shows the behavior of the contact angle in heartwood and sapwood as a function of time for different heat treatments. Contact angle values of heartwood are higher than sapwood for a same treatment condition. The lower the contact angle the greater is the wettability of the surface of the material. Surfaces with contact angles of $0^{\circ}$ have a complete wettability; surfaces with finite angle values are partially wettable (Daltin 2011); and a fully hydrophobic surface has an angle of $180^{\circ}$. Therefore, the teak heartwood presents lower wettability than the sapwood (Figure 2). Wang et al. (2015) observed a similar behavior for poplar heartwood and sapwood (Populus cathayana), with smaller contact angle values for the sapwood during the surface wetting. The teak heartwood has a large amount of hydrophobic extractives (Yamamoto et al. 1998) and this may explain its lower surface wettability.

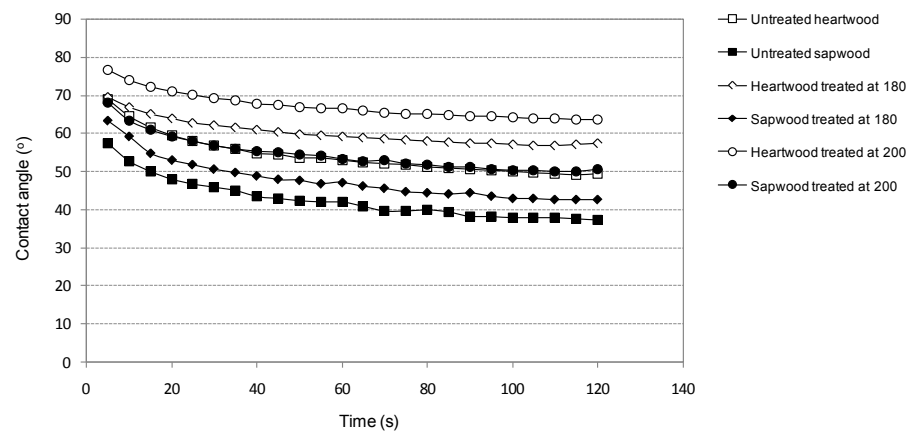

Figure 1. Contact angle behavior of the teak heartwood and sapwood as a function of time at different heat treatments.

Approximately up to $40 \mathrm{~s}$, the curves showed a greater slope than the starting point for all treatments indicating that the greatest contact angle variations occurred at the beginning (Figure 1). After $40 \mathrm{~s}$, the curves continued to decrease, but in a linear and constant way until reaching an equilibrium point close to $90 \mathrm{~s}$ (Figure 1). The wettability on the heterogeneous surface of the wood is complex since 
penetration of the liquid by capillarity occurs. According to the Forest Products Laboratory (2010), a surface with good wettability and good penetration absorbs the drop in up to $20 \mathrm{~s}$; if the drop spreads but the water remains on the surface after $40 \mathrm{~s}$, it has good wettability and low penetration, the adhesion may be difficult; and if after $40 \mathrm{~s}$, the drop remains with its original shape, with little spreading, it can present problems of adhesion due to the surface inactivation in which there is low wettability and low penetration. For example, on the heartwood surface treated at $200^{\circ} \mathrm{C}$, the drop remains practically with the same shape until $120 \mathrm{~s}$, indicating the presence of an inactive surface (Figure 2). On the other hand, on the untreated sapwood surface, a good drop spreading occurs indicating a greater wettability (Figure 2).

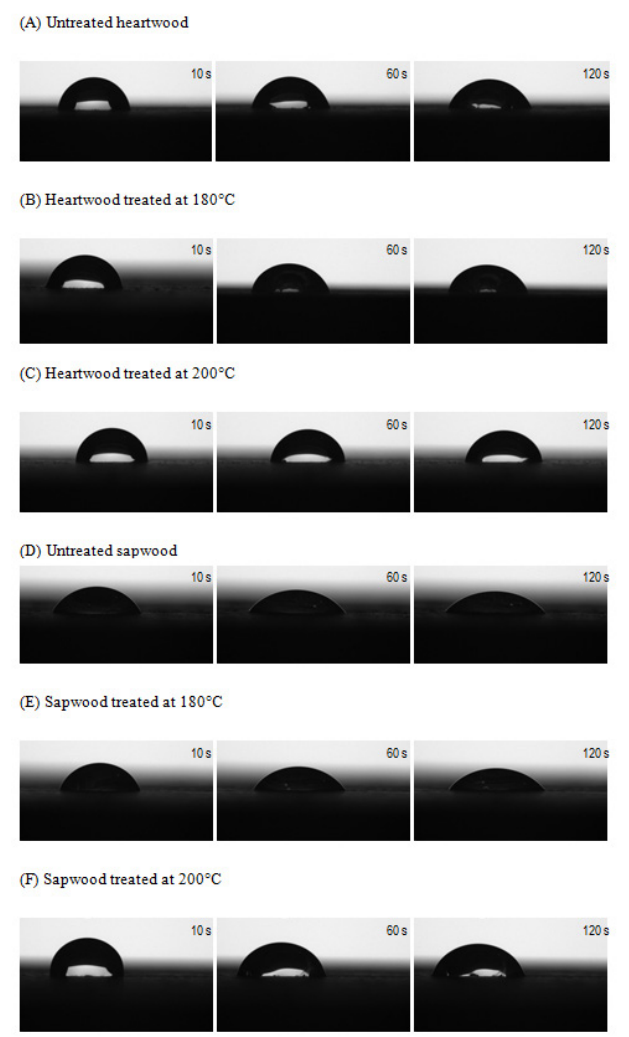

Figure 2. Drop shape changing on the teak heartwood and sapwood surfaces as a function of time to different heat treatments.

As the heat treatments became more severe, the wood surface presented lower wettability, resulting in higher contact angle values. Figure 2 shows the reduction in drop volume as a function of time due to the penetration of the liquid into the porous structure of the wood. Wang et al. (2015) observed a similar behavior for two wood species [poplar (Populus cathayana Rehd.) and Scots pine (Pinus sylvestris L.)] treated under different temperatures $\left(160,180,200,220\right.$ or $\left.240^{\circ} \mathrm{C}\right)$ for $4 \mathrm{~h}$. The heat treatment decreased the sapwood wettability of both wood species and the contact angle increased with the temperature increase (Wang et al. 2015). The contact angle in the sapwood treated at $200^{\circ} \mathrm{C}$ was similar to the untreated heartwood (Figure 1).

\section{Initial, final and average contact angle}

Table 1 shows the Anova results of the $\mathrm{CA}_{\text {initial }}$ and $\mathrm{CA}_{\text {final }}$. Significative differences were found between heartwood/sapwood and temperature levels for $\mathrm{CA}_{\text {initial }}$ and $\mathrm{CA}_{\text {final }}$. However, no significant interaction was observed between the independent variables (Table 1). 
Table 1. Analysis of variance (F values) at initial $\left(\mathrm{CA}_{\text {initial }}\right)$ and final $\left(\mathrm{CA}_{\text {final }}\right)$ contact angle of the teak wood.

\begin{tabular}{|c|c|c|}
\hline Source of variation & $\mathrm{CA}_{\text {inititiat }}$ & $\log 10 \mathrm{CA}_{\text {fint }}$ \\
\hline Type of wood & $37,73^{*}$ & $60,59^{*}$ \\
\hline Temperature & $14,27^{*}$ & $23,65^{*}$ \\
\hline Type of wood $\mathrm{x}$ temperature & $0,20^{\text {ns }}$ & $0,06^{\mathrm{ns}}$ \\
\hline
\end{tabular}

Table 2 shows the means values and standard deviation of the $\mathrm{CA}_{\text {initial }}$ and $\mathrm{CA}_{\text {final }}$ of the untreated and heat-treated heartwood and sapwood. Heartwood had higher $\mathrm{CA}_{\text {initial }}$ and $\mathrm{CA}_{\text {final }}$ values than sapwood when compared at a same temperature (Table 2). For example, untreated heartwood had an average $\mathrm{CA}_{\text {initial }}$ of $68,42^{\circ}$ while that of untreated sapwood was $57,87^{\circ}$. The average $\mathrm{CA}_{\text {final }}$ was of $49,28^{\circ}$ for untreated heartwood and $37,32^{\circ}$ for untreated sapwood (Table 2) showing that untreated heartwood has lower surface wettability than untreated sapwood.

Table 2. Descriptive statistical analysis (means and standard deviation) at initial $\left(\mathrm{CA}_{\text {inicial }}\right)$ and final $\left(\mathrm{CA}_{\text {final }}\right)$ contact angle of the teak wood.

\begin{tabular}{|l|l|l|l|l|}
\hline Wood & Temperature $\left({ }^{\circ} \mathrm{C}\right)$ & $\mathrm{CA}_{\text {initial }}\left({ }^{\circ}\right)$ & $\mathrm{CA}_{\text {final }}\left({ }^{\circ}\right)$ & $\log _{10} \mathrm{CA}_{\text {final }}$ \\
\hline \multirow{4}{*}{ Heartwood } & untreated & $68,42(8,0) \mathrm{b}$ & $49,28(10,9)$ & $1,68(0,11) \mathrm{bc}$ \\
\cline { 2 - 5 } & 180 & $69,71(9,4) \mathrm{ab}$ & $56,64(8,7)$ & $1,75(0,06) \mathrm{ab}$ \\
\cline { 2 - 5 } & 200 & $76,74(12,0) \mathrm{a}$ & $64,32(13,9)$ & $1,80(0,10) \mathrm{a}$ \\
\hline \multirow{3}{*}{ Sapwood } & untreated & $57,87(6,6) \mathrm{d}$ & $37,32(8,2)$ & $1,56(0,10) \mathrm{d}$ \\
\cline { 2 - 5 } & 180 & $60,97(9,5) \mathrm{cd}$ & $43,83(7,6)$ & $1,64(0,71) \mathrm{c}$ \\
\cline { 2 - 5 } & 200 & $68,35(8,8) \mathrm{bc}$ & $49,75(9,9)$ & $1,69(0,08) \mathrm{b}$ \\
\hline Total means & & $67,01(10,9)$ & $50,19(13,2)$ & $1,69(0,12)$ \\
\hline
\end{tabular}

Means with the same letter are not significantly different by the Tukey test. Values between brackets = standard deviation.

Table 3 presents the means values and standard deviation for $\mathrm{CA}_{\text {mean }}$ of the untreated and heat-treated heartwood and sapwood. The Wilcoxon-Mann-Whitney test ( $Z$ value) showed significant differences between $\mathrm{CA}_{\text {mean }}$ of the heartwood and sapwood where the sum of ranks of the heartwood was higher than sapwood with values of 7186 and 4139 , respectively $(Z=5,72 ; p<0,05)$ (non-tabulated data). The $\mathrm{CA}_{\text {mean }}$ of the untreated heartwood was $60,90^{\circ}$ while that of the untreated sapwood was $45,72^{\circ}$ (Table 3 ). The lower wettability of the untreated heartwood may be explained by the high extractive content. According to Gardner et al. (1995), extractives have a complex composition and the extractive group has a relevant effect on the wettability of the wood surface because some of them, when present at the interface (extractive-liquid), can orientate their hydrophilic functional group to the polar group of the liquid establishing hydrogen bonds, and thus provide an apparent change in the surface tension of the liquid, or even in the interfacial tension between wood-extractive-liquid decreasing or increasing the surface energy of the wood and consequently causing a higher or lower wettability. 
Table 3. Descriptive statistical analysis (means and standard deviation) and F values to average contact angle $\left(\mathrm{CA}_{\text {mean }}\right)$ of the teak wood.

\begin{tabular}{|c|c|c|}
\hline \multirow{2}{*}{ Temperature $\left({ }^{\circ} \mathrm{C}\right)$} & Heartwood & Sapwood \\
\hline & $\mathrm{CA}_{\text {mean }}\left({ }^{\circ}\right)$ & $\mathrm{CA}_{\text {mean }}\left({ }^{\circ}\right)$ \\
\hline Untreated & $54,18(10,3) \mathrm{c}$ & $45,91(5,9) \mathrm{c}$ \\
\hline 180 & $60,10(9,4) b c$ & $48,81(7,4) b c$ \\
\hline 200 & $68,41(14,1) \mathrm{a}$ & $54,26(9,21) \mathrm{a}$ \\
\hline Total means & $60,90(12,7)$ & $45,72(8,3)$ \\
\hline F value & $9,72 *$ & $6,34^{*}$ \\
\hline
\end{tabular}

The effect of temperature increase is remarkable in $\mathrm{CA}_{\text {initial }}$ and the $\mathrm{CA}_{\text {final }}$. The temperature increase caused a gradual increase in the contact angle independent of wood type (Table 2). For the $\mathrm{CA}_{\text {initial }}$, only wood treated at $200^{\circ} \mathrm{C}$ was significantly different from untreated wood for both heartwood and sapwood, while treatments at $180^{\circ} \mathrm{C}$ and $200^{\circ} \mathrm{C}$ did not have difference between them. The treatment at $200^{\circ} \mathrm{C}$ caused an average increase of $12 \%$ and $18 \%$ in the $\mathrm{CA}_{\text {initial }}$ of the heartwood and sapwood, respectively.

For $\mathrm{CA}_{\text {final, }}$, heartwood treated at $200^{\circ} \mathrm{C}$ presented an increase of $30,5 \%$ when compared to untreated heartwood. The sapwood presented an average increase in the $\mathrm{CA}_{\text {final }}$ of $17 \%$ and $33 \%$ after treatment at $180^{\circ} \mathrm{C}$ and $200^{\circ} \mathrm{C}$, respectively (Table 2). These results show that the treatment at $180^{\circ} \mathrm{C}$ does not significantly affect the wettability of the teak wood surface but on the other hand the surface wettability is decreased following the treatment at $200^{\circ} \mathrm{C}$.

The $\mathrm{CA}_{\text {mean }}$ of the heartwood had an average increase of $27 \%$ following treatment at $200^{\circ} \mathrm{C}$ while for sapwood, it average increase about $18 \%$ at the same temperature (Table 3 ). However, the treatment at $180^{\circ} \mathrm{C}$ did not affect the $\mathrm{CA}_{\text {mean }}$ of the heartwood or sapwood.

Heartwood treated at $200^{\circ} \mathrm{C}$ showed the lowest wettability while untreated sapwood showed the highest wettability (Table 2). The low wettability following the treatment at $200^{\circ} \mathrm{C}$ is due to the surface inactivation. Our results corroborate with those obtained by other authors (Sernek et al. 2004, Kocaefe et al. 2008, Cademartori et al. 2013) to different wood species. A lower surface wettability was found to the Fraxinus americana and Acer rubrum woods treated at $205-215^{\circ} \mathrm{C}$ (Kocaefe et al. 2008) and Eucalyptus cloeziana wood treated at $180-240^{\circ} \mathrm{C}$ (Cademartori et al. 2013). The surface inactivation is caused by the migration of hydrophobic extractives in a natural process of the wood or by physic-chemical modifications (Forest Products Laboratory 2010). Sernek et al. (2004) study the chemical modification of the heat-treated wood assessed by X-ray photoelectron spectroscopy (XPS) which provides the elemental composition (carbon and oxygen) of the wood surface. These authors evaluated the surface of two species (Liriodendron tulipifera and Pinus taeda) treated at $156^{\circ} \mathrm{C}, 172^{\circ} \mathrm{C}$ and $187^{\circ} \mathrm{C}$ and observed that the wood exposed to the most severe temperature had the highest $\mathrm{C} 1 / \mathrm{C} 2$ ratio in comparison to the untreated wood - $\mathrm{C} 1$ component corresponds to extractives and lignin and $\mathrm{C} 2$ component may arise from all constituents of the wood, but predominantly from cellulose. Also, Wang et al. (2015) evaluated the relation between the dynamic wetting behavior and chemical components of the heat-treated woods using three parameters (mass loss, $\mathrm{C} 1 / \mathrm{C} 2$ ratio and $\mathrm{O} / \mathrm{C}$ ratio) and they observed an increase in the $\mathrm{C} 1 / \mathrm{C} 2$ ratio and mass loss and a decrease in the $\mathrm{O} / \mathrm{C}$ ratio. The dynamic wetting showed a better correlation with $\mathrm{O} / \mathrm{C}$ ratio than $\mathrm{C} 1 / \mathrm{C} 2$ ratio, indicating that the amount of $\mathrm{OH}^{-}$groups on wood surface played a fundamental role in the dynamic behavior of wood surface wetting. The dehydration reactions of the hemicelluloses were able to degrade $\mathrm{OH}^{-}$groups during the heat treatment, which caused a decrease in water penetration on the wood surface.

Pétrissans et al. (2003) studied the chemical modifications of four wood species treated at $240^{\circ} \mathrm{C}$ assessed by ${ }^{13} \mathrm{C}$ nuclear magnetic resonance (NMR) analysis and observed important differences between untreated and heat-treated woods at the level of crystallinity of carbohydrates. The $\mathrm{C} 4$ and C6 carbons of the cellulose resulted in two typical peaks of 89 and $85 \mathrm{ppm}$ for the crystalline cellulose 
region and 66 and $65 \mathrm{ppm}$ for the amorphous region in the treated and untreated woods, respectively. The considerable increase in peaks at 89 and $66 \mathrm{ppm}$ in the heat-treated wood indicates greater crystallinity which leads to a more hydrophobic material. Several studies have reported that the sorption of water by amorphous cellulose is higher than for crystalline celluloses, and therefore the higher hydrophobicity of heat-treated wood can be explained also by the increase cellulose crystallinity (Pizzi and Stephanou 1993).

\section{CONCLUSIONS}

Heartwood had lower wettability than sapwood, even after heat treatment.

The heat treatment reduced the wettability of the teak heartwood and sapwood surfaces, especially in the wood treated at $200^{\circ} \mathrm{C}$ due to the surface inactivity.

Studies on physico-chemical modifications of the heartwood and sapwood of teak are recommended for a better understanding of the wettability of the teak wood surface.

\section{REFERENCES}

Awoyemi, L.; Jones, I.P. 2011. Anatomical explanations for the changes in properties of western red cedar (Thuja plicata) wood during heat treatment. Wood Science and Technology 45(2): 261-267.

Bernabei, M.; Salvatici, M.C. 2016. In situ ESEM observations of spruce wood (Picea abies Karst.) during heat treatment. Wood Sci Technol 50: 715-726.

Bhuiyan, T.; Hirai, N. 2000. Changes of crystallinity in wood cellulose by heat treatment under dried and moist conditions. $J$ Wood Sci 46: 431-436.

Cademartori, P.H.G.; dos Santos, P.G.; Serrano, L.; Labidi, J.; Gatto, D.A. 2013. Effect of thermal treatment on physicochemical properties of Gympie messmate wood. Industrial Crops and Products 45:360-366.

Daltin, D. 2011. Tensoativos: química, propriedades e aplicações. Blucher, São Paulo.

Esteves, B.; Videira, R.; Pereira, H. 2011. Chemistry and ecotoxicity of het-treated pine wood extractives. Wood Science and Technology 45(4): 661-676

Forest Products Laboratory. 2010. Wood handbook: wood as an engineering material. General Technical Report FPL-GTR-190. Department of Agriculture, Forest Service, Forest Products Laboratory, Madison, WI: U.S.

Garcia, R.A.; Lopes, J.O.; Nascimento, A.M.; Latorraca, J.V.F. 2014. Color stability of weathered heat-treated teak wood. Maderas. Ciencia y tecnología 16(4): 453-462.

Gardner, D.J.; Wolcott, M.P.; Wilson, L.; Huang. Y; Carpenter, M. 1995. Our understanding of wood surface chemistry in 1995. Proc. No. 7296. Wood Adhesives 1995. Forest Products Society, Madison, WI, USA.

Giebeler, E. 1983. Dimensional stabilization of wood by moisture-heat-pressure treatment. Holz als Roh-und Werkstoff 41(1): 87-94.

Kocaefe, D.; Poncsák, S.; Doré, G.; Younsi, R. 2008. Effect of heat treatment on the wettability of white ash and soft maple by water. Holz als Roh-und Werkstoff 66(5): 355-361. 
Lekounougou, S.; Kocaefe, D. 2013. Bioresistance of thermally modified Populus tremuloides (North American Aspen) wood against four decay fungi. International Wood Products Journal 4(1): 46-51.

Lopes, J.O.; Garcia, R.A.; Nascimento, A.M.; Latorraca, J.V.F. 2014. Color uniformization of the Young teak wood by heat treatment (in portuguese). Revista Árvore 38(3): 561-568.

Niamké, F. B.; Amusant, N.; Charpentier, J.-P.; Chaix, G.; Baissac, Y.; Boutahar, N.; Adima, A. A.; Kati-Coulibaly, S.; Jay-Allemand, C. 2011 Relationships between biochemical attributes (non-structural carbohydrates and phenolics) and natural durability against fungi in dry teak wood (Tectona grandis L. f.). Annals of Forest Science (68): 201-211.

Pizzi, A.; Stephanou, A. 1993. On the chemistry, behavior, and cure acceleration of phenolformaldehyde resins under very alkaline conditions. Journal of Applied Polymer Science 49(12): 21572170.

Popescu, C.M.; Popescu, M.C. 2013. A near infrared spectroscopic study of the structural modifications of lime (Tilia cordata Mill.) wood during hydro-thermal treatment. Spectrochimica Acta Part A: Molecular and Biomolecular Spectroscopy 115: 227- 233.

Sernek, M.; Kamke, F.A.; Glasser, W.G. 2004. Comparative analysis of inactivated wood surface. Holzforchung 58: 22-31.

Tshabalala, M.A. 2005. Surface characterization. In Rowell, R.M. (Ed.). Handbook of wood chemistry and wood composites. CRC Press, Boca Raton, Florida.

Wang, W.; Zhu, Y.; Cao, J.Z.; Sun, W.J. 2015. Correlation between dynamic wetting behavior and chemical components of thermally modified wood. Applied Surface Science 324: 332-338.

Yamamoto, K.; Simatupang, M.H.; Hashim, R. 1998. Caoutchouc in teak wood (Tectona grandis): Formation, location, influence on sunlight irradiation, hydrophobicity and decay resistance. Holz als Roh- und Werkstoff 56(3): 201-209.

Yuan, Y.; Lee, T.R. 2013. Contact angle and wetting properties. In: Bracco, G.; Holst, B. (Eds.) Surface Science Techniques. Springer Series in Surface Sciences 51. 